\title{
Screening for proteinuria in a rheumatology clinic: comparison of dipstick testing, 24 hour urine quantitative protein, and protein/creatinine ratio in random urine samples
}

\author{
STUART H RALSTON, ${ }^{1}$ NELL CAINE, ${ }^{2}$ IAIN RICHARDS, \\ DENIS O'REILLY, ROGER D STURROCK, ${ }^{2}$ AND HILARY A CAPELL \\ From the ${ }^{\prime}$ Centre for Rheumatic Diseases and the ${ }^{2}$ Biochemistry Department, Glasgow Royal Infirmary, \\ Glasgow
}

SUMMARY Measurements of protein/creatinine ratio in 'spot' urine samples were compared with measurements of 24 hour quantitative proteinuria and side room 'dipstick' testing in 104 samples from 90 patients presenting consecutively to a rheumatology unit. Linear regression analysis showed a highly significant correlation between the random urinary protein/creatinine ratio and total protein excretion in 24 hour urine samples $(r=0.92, p<0.001, y=6.55 x+0.04)$. Although an approximation of 24 hour urinary protein excretion could have been made from the regression line: 24 hour urine protein $=6.55 \times$ protein/creatinine ratio $+0.04(\mathrm{~g} / \mathrm{l})$, there was a wide scatter of values, particularly in patients with $>1 \mathrm{~g} / 24 \mathrm{~h}$ urinary protein excretion. Nevertheless, significant proteinuria $(>300 \mathrm{mg} / 24 \mathrm{~h})$ could have been confirmed or excluded with a sensitivity and specificity of $97 \%$ by adopting random protein/creatinine values of $<0.04$ as 'normal'. Specificity and sensitivity could have been increased to $100 \%$, however, by excluding patients with values lying between $0 \cdot 01$ and $0 \cdot 10$ as all the false negatives $(n=3)$ and false positives $(n=3)$ lay within this range. In comparison, dipstick testing, although $100 \%$ sensitive, had a poor specificity due to the high false positive rate $(40 / 83(48 \%))$ in patients with $1+$ to $3+$ readings. Assessment of random urinary protein/creatinine ratio may obviate the need for 24 hour urine collections in the initial assessment of suspected proteinuria. A wider application of this technique seems indicated in view of the obvious advantages in terms of cost, time, and patient convenience.

Screening for proteinuria is a common requirement in rheumatological practice, particularly in patients who are receiving second line agents such as gold and penicillamine. In current clinical practice it is usual to screen for proteinuria by dipstick testing, and when a positive result is obtained to confirm or refute the presence of proteinuria by a 24 hour collection. ${ }^{1}$ As 24 hour urine collections are laborious, costly, and inconvenient the present study was designed to see if the 24 hour urinary protein excretion could be assessed accurately from the protein/creatinine ratio in random urine samples-a method which has previously been shown to corre-

Accepted for publication 13 February 1988.

Correspondence to Dr Stuart H Ralston, Centre for Rheumatic Diseases, Glasgow Royal Infirmary, 84 Castle Street, Glasgow G4 OSF. late well with measured 24 hour urinary protein, excretion in various other clinical circumstances. ${ }^{2-6}$

\section{Patients and methods}

One hundred and four samples from 90 patients who presented consecutively to the centre for rheumatic diseases over a six month period were studied. In all cases a 24 hour urine specimen had been requested as part of the patients' routine clinical management because of a positive screening test for protein on dipstick examination. Forty seven $(45 \%)$ of the urine collections had been performed on inpatients and the remainder on outpatients.

The procedure for urine testing was as follows: a random urine sample was obtained from all patients for dipstick testing (Multi-stix; Ames and Co), which was performed by the on duty nursing staff. 
Patients with positive results (i.e., trace to ++++ ) were asked to provide a 24 hour urine sample in the usual way. In addition, these patients were asked to collect a random urine sample $(20 \mathrm{ml}$ in a plain universal container) either before or after completion of the 24 hour sample, but were specifically instructed not merely to take an aliquot from the 24 hour sample. Random urine samples from two patients failed to reach the laboratory. giving a total of 102 samples in which full data were available. Venous blood samples were taken from all patients at the end of the 24 hour urine collection.

Serum albumin and creatinine were measured with an SMAC II autoanalyser (Technicon Co Ltd, Tarrytown. USA), by the BCG and alkaline picrate methods respectively. Urine creatinine was measured on a Hitachi 704 discrete autoanalyser (Boehringer Mannheim $\mathrm{GmbH}$ ) by the alkaline picrate method (kit reagents from Boehringer Mannheim $\mathrm{GmbH}$ ). Urinary protein was measured by the ponceau-S TCA method. ${ }^{7}$ This method has a detection limit of $50 \mathrm{mg}$ protein/1 in our hands.
Statistical tests used in analysis of the data were Spearman's rank correlation coefficient and linear regression analysis by the sum of least squares. method.

\section{Results}

Diagnostic categories of the patients studied were as follows: rheumatoid arthritis 72 patients $(80 \%) \stackrel{\mathbb{D}}{\Omega}$ seronegative spondarthritis seven $(8 \%)$ connective tissue disease four $(4 \%)$, miscellaneous seven $(8 \%) . \vec{\circ}$ Most of the patients were receiving non-steroida? anti-inflammatory drugs or analgesics, or both $\vec{\omega}$ Forty four $(61 \%)$ of the patients with rheumatoid? arthritis were also receiving gold or penicillamine treatment. Four patients had, or were subsequently discovered to have, amyloid disease (three rheuma-co toid arthritis, one ankylosing spondylitis). The median age of the study group was 58 years (rangee 15-78). Median serum creatinine was $75 \mu \mathrm{mol} / \mathrm{P}$ (range 35-600), median serum albumin was $35 \mathrm{~g} / \mathrm{L}$ (range 21-47). Median creatinine clearance was 840 $\mathrm{ml} / \mathrm{min}$ (range 5-246).

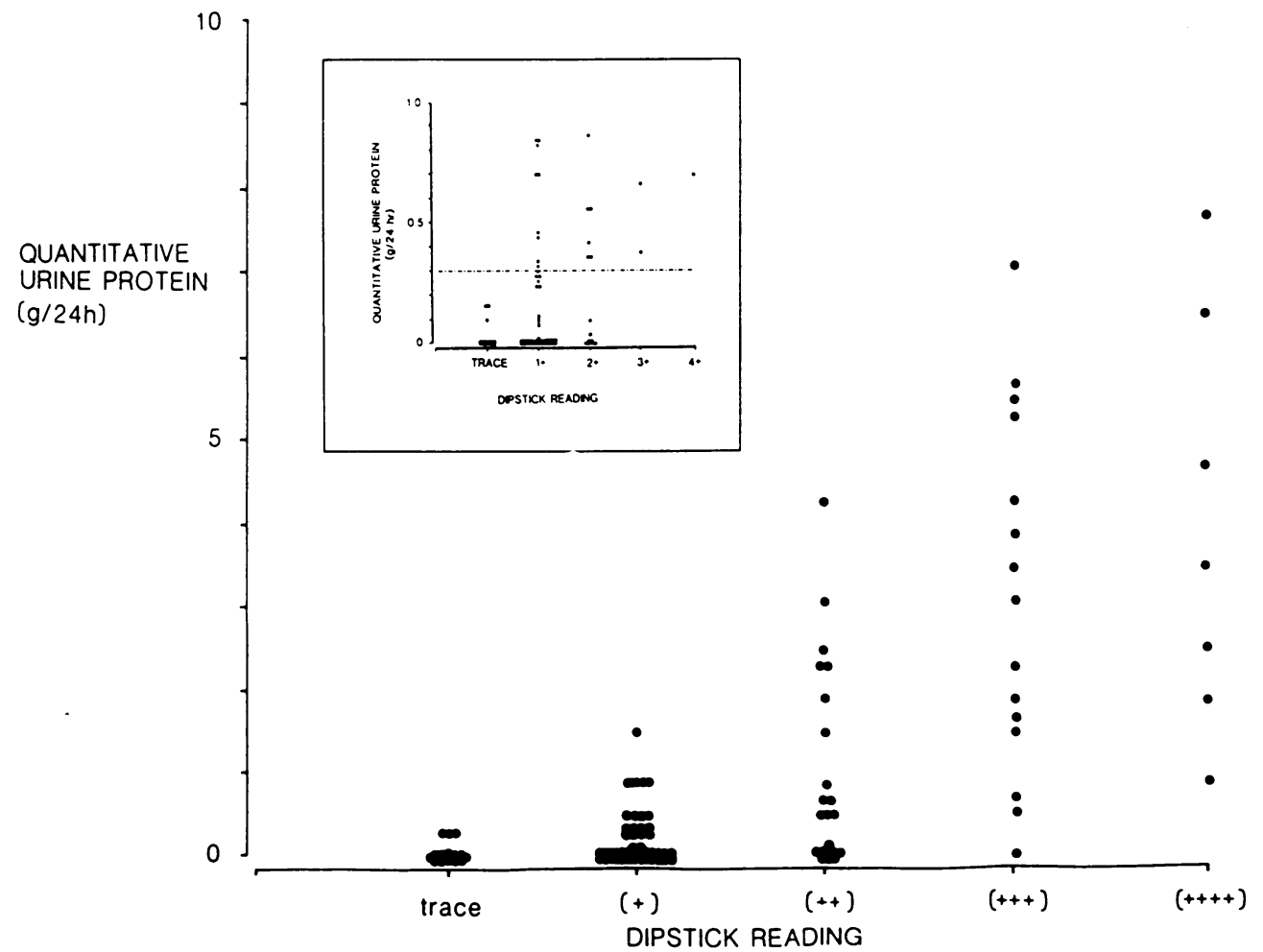

Fig. 1 Comparison of dipstick testing and 24 hour quantitative protein excretion in 104 patient samples. Inset shows expanded view of data in patients with $<1000 \mathrm{mg} / 24 \mathrm{~h}$ urine protein excretion. The number of data points in patients with 24 hour protein values of 0 were trace $=12,1+=25,2+=6,3+=1$. 


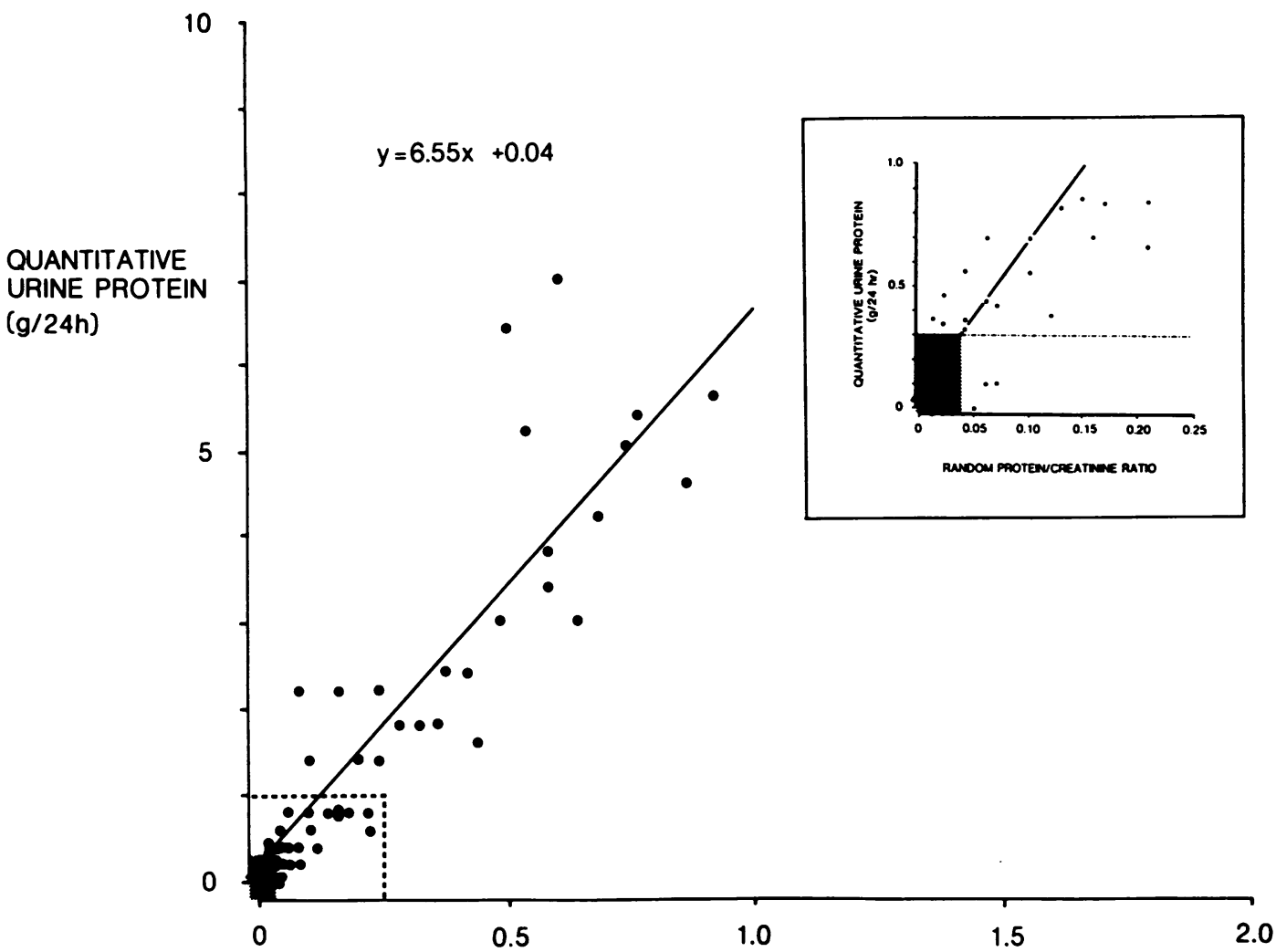

RANDOM URINE PROTEIN/CREATININE RATIO

$(\mathrm{g} / \mathrm{l} / \mathrm{mmol} / \mathrm{l})$

Fig. 2 Comparison of random protein/creatinine ratio and 24 hour quantitative urine protein excretion in 102 patient samples. Note that no protein was detected in either sample in 42 cases (points omitted for clarity). Inset (note change of scale in axes) shows expanded view of data in patients with 24 hour urine protein excretion of less than $1000 \mathrm{mg}$ and protein/creatinine less than 0.25 (the area enclosed by interrupted line in the main panel). The shaded area indicates the normal range for protein/creatinine ratio, as calculated from the regression line, for 24 hour urine protein excretion of $<300$ $m g$.

Fig. 1 shows the results of dipstick testing in relation to the total urinary protein excretion over 24 hours. The inset shows details of these data in patients whose 24 hour urine protein excretion was less than $1000 \mathrm{mg}$. Twenty four hour urinary protein was less than $300 \mathrm{mg}$ in all 15 of the patients with a trace of proteinuria on dipstick testing. The false positive rate, as defined above, was $76 \%$ in those with $1+$ on dipstick $(n=46), 8 / 21(38 \%)$ in those with $2+, 1 / 15(7 \%)$ in those with $3+$, and none $(0 \%)$ in those with $4+$.

Preliminary analysis showed a significant correlation between absolute protein concentrations $(\mathrm{g} / \mathrm{l})$ in the random urine sample and 24 hour total protein excretion (Spearman's test: $r=0.88, p<0.001$; linear regression: $r=0 \cdot 70, p<0 \cdot 001, y=0 \cdot 30 x+0 \cdot 64)$. The closest correlation was obtained, however, when the protein excretion in the random sample was expressed as a function of the urinary creatinine concentration. The random urine protein/creatinine ratio was therefore used in subsequent analysis.

Fig. 2 shows the relation between the protein/ creatinine ratio in random urine samples and the 24 hour urinary protein concentrations. The inset shows detail from the patient samples where the total excretion of protein was less than $1000 \mathrm{mg}$ in 24 
hours. In 42 subjects no protein was detected in either sample. These points are omitted from the figures for reasons of clarity.

There was a highly significant correlation between the random protein/creatinine ratio and 24 hour urinary protein excretion, using Spearman's rank correlation coefficient $(r=0 \cdot 91 . p<0 \cdot 001)$. Linear regression analysis yielded a similarly significant correlation $(r=0.92, p<0.001)$, with a regression line of $y=6 \cdot 55 x+0 \cdot(04$. When the 24 hour quantitative urine protein is plotted on the $x$ axis (not shown) the regression line is $y=0 \cdot 13 x+0 \cdot 01$.

From the regression line in Fig. 2 an estimate of the 24 hour urinary protein excretion $(\mathrm{g} / \mathrm{l})$ could be made by multiplying the urine protein/creatinine ratio $(\mathrm{g} / \mathrm{l} / \mathrm{mmol} / \mathrm{l})$ by 6.55 and adding 0.04 . Unfortunately, the skewed distribution of the data renders calculation of confidence intervals unhelpful as the variation around the regression line was much wider at higher values of protein excretion than at lower values. Nevertheless, by using the regression equation we could have assigned patients into groups of significant proteinuria or insignificant proteinuria (i.e., $>300 \mathrm{mg} / 24 \mathrm{~h}$ or $\leqslant 300 \mathrm{mg} / 24 \mathrm{~h}$ ), with a sensitivity and specificity of $97 \%$, by considering protein/creatinine values of $<0.04$ as normal and those of 0.04 or above as abnormal. Both sensitivity and specificity could have been increased to $100 \%$. however, by excluding patients with protein/ creatinine values of $0 \cdot 01-0 \cdot 10$ as all the false positives and false negatives lay within this range.

\section{Discussion}

In recent years various workers have found a close correlation between 24 hour urinary protein measurements and random urinary protein/ creatinine ratio in normal subjects, ${ }^{2-5}$ patients with primary renal pathology..$^{2-5}$ and patients with systemic lupus erythematosus." In this series of 104 patient samples-the largest reported study of patients with suspected proteinuria-we found a similarly close correlation between the protein/ creatinine ratio and 24 hour urine protein excretion. We were also interested, however, to assess whether the protein/creatinine ratio would be sufficiently accurate to replace 24 hour urine collections in clinical practice; although urinary protein excretion is generally recognised to be less than $150 \mathrm{mg} / 24 \mathrm{~h}$ in normal subjects, ${ }^{\circ}$ few clinicians would consider urinary protein levels of $<200 \mathrm{mg} / 24 \mathrm{~h}$ to be worthy of investigation. Indeed, in rheumatological practice, a value of $300 \mathrm{mg} / 24 \mathrm{~h}$ has been considered to be the level at which one would consider stopping treatment with gold or penicillamine owing to nephrotoxicity. ${ }^{9}$ If $300 \mathrm{mg}$ of protein per 24 hours is taken as an arbitrary cut off point the presence of absence of significant proteinuria could have beers. predicted from the random urinary protein creatinine ratio with a sensitivity and specificity of? $97 \%$. Moreover, both sensitivity and specificit? could have been increased by excluding patient호 with protein/creatinine values lying between $(0 \cdot())$ and $(0 \cdot 10$ as all the false positives and false negative $\mathbb{D}$ lay within this range.

This is a substantial improvement on dipstick testing as, in agreement with previous reports? neither the presence nor severity of proteinuria could have been confidently predicted by dipsticlo testing alone. ${ }^{31011}$ Thus where dipstick reading ranged from $1+$ to $3+$, there was a high incidence $(40 / 83(48 \%))$ of false positives, though it should be emphasised that dipstick readings of $4+$ correctliv predicted the presence of significant proteinuria in all cases, whereas none of the patients with trace readings had significant proteinuria.

In many cases precise assessment of the degree of proteinuria is unnecessary. Rather, the clinician io more interested in classifying patients into broad categories by the degree of proteinuria, in order to decide which patients require further investigation. or in the case of gold and penicillamine treatmeĝt to decide which patients can safely contim therapy. In this study we found that the correlation between the random protein/creatinine ratio and 2 hour quantitative protein measurements was suffi 근 ciently close to be of practical value in all the above respects. A wider application of this technique seems indicated in view of its advantages in terms of time. increased patient convenience, and reduces cost.

We gratefully acknowledge the help of Sisters M Allison. M King C McNiven. C Maxwell. and their staff for supervising collection of the samples and Ms Dorothy McKnight for help with the processing of data and statistical analysis.

\section{References}

Robson I S. The examination of urinc hlood vomit facces and cerebrospinal fluid. In: McLeod J. ed. Clinical examination. +1 p ed. Edinburgh: Churchill Livingstone. 1976: 425-56.

2 Shaw A B. Risdon P. Lewis-Jackson J. Protein creatinine inde? and Albustix in assessment of proteinuria. Br Med J 1983: 287 929-32.

3 Barratt T M. McLaine P N. Soothill J F. Albumin excretion as measure of glomerular dysfunction in children. Arch Dis (hili 1970: 45: 496-501.

4 Ginsberg J M. Chang G S. Matarese R A. Garella S. Use of single-voided urine samples to estimate quantitative proteinuria. $N$ Engl J Med 1983: 309: 1543-6.

5 Lemann J. Doumas B T. Proteinuria in health and diseas $\bar{D}$ assessed by measuring the urinary protein/creatinine ratio. Clis Chem 1987: 33: 297-9.

6 Sessoms S. Mehta K. Kovarsky J. Quantitation of proteinuria in systemic lupus erythematosus by use of a random. spot urin collection. Arthritis Rheum 1983: 26: 918-20. 
7 Pesce M A, Strande C S. A new method for determination of protein in cerebrospinal fluid and urine. Clin Chem 1973; 19: 1265-7.

8 Morrison J B I, Davidson J M, Kerr D N S. Clinical physiology of the kidney: tests of renal function and structure. In: Weatherall D J, Ledingham J G G, Warrell D A, eds, Oxford textbook of Medicine. Vol 2. Oxford: Oxford University Press, 1983: 18.4-18.19.
9 Capell H A, Daymond T J. Dick W C. Rheumatic diseases. Berlin: Springer, 1983: 141-58.

10 Gyure W L. Comparison of several methods for semiquantitative determination of urinary protein. Clin Chem 1977; 23: 876-9.

11 Rennie D B, Keen H. Evaluation of clinical methods in detecting proteinuria. Lancet 1967; ii: 489-92. 